International Journal of Business Management and Economic Review

Vol. 4, No. 03; 2021

ISSN: 2581-4664

\title{
THE EFFECT OF TEMPERAMENT AND CHARACTER OF BUSINESS PEOPLE ON ENTREPRENEURSHIP ORIENTATIONS AND ECONOMIC DEVELOPMENT LEVEL OF A LOW-INCOME PROVINCE
}

\author{
Fuat Oktay \\ Head of the Coordination Council for the Improvement of Investment Environment, Ankara, Turkey \\ http://doi.org/10.35409/IJBMER.2021.3258
}

\begin{abstract}
The aim of this research is to examine the effect of temperament and character of business people on entrepreneurial orientations and economic development level of the province. The sample of the study is 224 business people operating in Yozgat which is a low-income province in Turkey. Entrepreneurship Orientation Scale and the Novelty Seeking Scale, Self-Directedness and Cooperativeness Scale of the Temperament and Character Inventory were used in the research. Research data were analyzed by arithmetic mean, standard deviation, $t$ test, one-way analysis of variance, Mann Whitney-U test, Kruskal Wallis- $\mathrm{H}$ test, correlation analysis and regression analysis. Based on the findings, it is found that in general the level of entrepreneurship orientation of business people is high, the level of novelty seeking, selfdirectedness and cooperativeness are above average. A negative, low level and significant relationship was found between the entrepreneurship orientation variable and the selfdirectedness variable. As a result of the regression analysis, it was found that self-directedness is a significant predictor of entrepreneurship orientation. In addition, it was determined that the temperament and character of business people had positive reflections on the economic development level of their province.
\end{abstract}

Keyword: Entrepreneurship orientation; temperament; character; business person

\section{INTRODUCTION}

Entrepreneurship, which expresses the motivation and capacity of a person to move towards the opportunity to identify an opportunity and to create a new value or to achieve economic success independently or within an organization (Keskin 2017), is an activity that includes discovering, evaluating and benefiting from the opportunities of presenting new goods and services, forms of organization, markets, processes and raw materials to the market through organizing efforts that did not exist previously (Shane 2003; as cited in Eroğlu, Vural \& Eroğlu 2019). In another definition, entrepreneurship is the process of doing something new and different in order to create wealth for the individual and add value to the society (Kao 1993). Therefore, when the concept of "entrepreneur" or "entrepreneurship" is mentioned, the first thing that comes to mind is that an entrepreneurial individual establishes a new business in new markets (Aldemir 2011). In this context, entrepreneurship can be conceptualized as the discovery of opportunities and then the creation of new economic activities through establishing a new 


\section{International Journal of Business Management and Economic Review}

Vol. 4, No. 03; 2021

ISSN: 2581-4664

organization (Reynolds 2005). However, according to Cunningham and Lischeron (1991, as cited in Yilmaz, Karahan \& Arslan 2019), employees are also described as internal entrepreneurs due to some of their entrepreneurship values. In this way, employees' going beyond traditional entrepreneurial behavior and taking risks related to their work while working in an organization without setting up their own businesses and focusing on innovation and utilizing opportunities in the market with new products with profitable business ideas bring the change simultaneously.

\section{LITERATURE REVIEW}

Entrepreneurship orientation, which is one of the tools that businesses may use to provide sustainable competitive advantage and become more viable, is regarded as an element of the strategic orientation of companies (İnce \& Topçu 2017). A number of researchers focused on the features clarifying entrepreneurship orientation (Gartner 1985; Smith et al., 1988). Miller (1983) stated that entrepreneurship orientation consists of three dimensions: innovation, risk taking and proactivity. Proactivity as an opportunity-seeking behavior is a forward-looking perspective for researching opportunities by acting in anticipation that change will take place and the environment will take shape, offering new products and services to the market compared to competitors. Proactivity is vital because it gives organizations the opportunity to be the first to act in the competitive environment giving them the advantage of being exemplary in the race and the opportunity to win rewards in the market. Risk taking is defined as the act of taking bold steps for entering into unknown or new markets for the organization where the results are unpredictable for investment in a business full of uncertainties and with a very high level of debts. Innovativeness means developing and implementing new methods for managing personnel and improving the design of products, carrying out organizational change in structure, application and creating models, and products or offering them to customers (Yllmaz et al., 2019).

Although entrepreneurship is handled in many different ways in many different approaches, it is basically accepted as a decision-making behavior (Yener 2018). Although such is emphasized that it is independent of size or age (Cuervo, Ribeiro \& Roig 2007) it is reported that some personality traits are influential on the entrepreneurial tendency (Çiçekoğlu \& Afşar 2017), which expresses the behavioral, practical and intellectual tendencies of the person before making any attempt (Sarıtaş \& Duran 2017). As a result of recent studies, it is reported that there are some differences between entrepreneur and non-entrepreneurs due to personality traits. These concepts, which are about personality and sometimes used as a synonym for personality, include character and temperament terms (Taşlıyan, Çiçeklioğlu \& Yılmaz, 2017). Although the words "temperament, character and personality" are used incorrectly interchangeably in daily life, these concepts have different meanings (Totan, Aysan \& Bektaş 2010). Temperament refers to attitudes and behaviors based on structural, genetic and biological groundings. The view that temperament has a biological background and shapes personality traits is supported by current clinical studies (Yılmaz, Gençer, Ünal \& Aydemir 2014). In other words, temperament, which is a concept that explains the emotional aspect of personality (Özgün 2007), corresponds to the perception, connection and motivation processes underlying the integration of emotional skills and habits. Character corresponds to symbolization and abstraction processes based on conceptual learning (Arkar, Sorias, Tunca, Şafak, Alkın, Akdede \& Cimilli 2005). The word 


\section{International Journal of Business Management and Economic Review}

Vol. 4, No. 03; 2021

ISSN: 2581-4664

"character" is the most confused term with personality. But character is just one of the components that are effective in the formation of personality. The character is defined as the traits that are not hereditary traits and are acquired by the individual later starting in the early stages (Taşlıyan et al.,2017).

In today's world, self-realization of individuals with entrepreneurial spirit in the society is very important for the social and economic development of a country or region. Increase in entrepreneurship means increase in innovation, competition, efficiency, quality and employment, and that means acceleration of economic development (Özkul \& Dulupçu 2007). Despite the high economic growth achieved in recent years in Turkey, large development disparities between regions are still ongoing. Different sectoral structures and different efficiency levels of the economies of different regions are shown as important determinants of regional disparities in Turkey (Memis \& Paksoy 2007). Undoubtedly, the temperament and character of the people living in that region are also thought to be effective on such a result. Thereby, this research was carried out to study the effect of temperament and character traits of business people on entrepreneurial tendencies and economic development level of their province. In the literature, there are studies examining the effects of temperament and character traits of individuals on different variables (Çiçeklioğlu \& Af̧̧ar 2017; Taşliyan et al., 2017; Totan et al., 2010) however, any research studying the effect of temperament and character traits of business people on entrepreneurship orientations and economic development level of their province has not been found.

The Gross Domestic Product (GDP) in Turkey is worth 771,35 billion US dollars in 2018, according to official data from the World Bank. According to current GDP ranking Turkey is the world's 18th and Europe's 7th largest economy. (World Bank 1978). Meanwhile, GDP per capita is 9693 US dollars. (TUIK 2020) Depending on these data following assumptions are used to classify provinces of Turkey in this study:

- Provinces that have higher GDP per capita than the country average are defined as "highincome" provinces.

- Provinces that have GDP per capita between the country average and 6000 US dollars in 2018 are defined as "middle-income" provinces

- Provinces that have lower GDP per capita than 6000 US dollars in 2018 are defined as "low-income" provinces.

The overall aim of this research is to examine the effect of temperament and character of business people in one of a low-income province in Turkey, Yozgat, on entrepreneurial orientations and economic development level of the province. In line with this general purpose, answers to the following questions were sought in the research:

1) What are the levels of entrepreneurship orientation and the level of novelty seeking, selfdirectedness and cooperativeness, which are the sub-scales of temperament and character inventory of business people in Yozgat province?

2) Do entrepreneurship orientation, novelty seeking, self-directedness and cooperativeness levels of business people in Yozgat province show a significant difference according to the gender, age, tasks, experience in the sector, working time in their institutions, the operation period of their institutions, the sector they work in, the number of employees in their institutions, general success of their institution and whether their institution export or not? 
Vol. 4, No. 03; 2021

ISSN: 2581-4664

3) Are novelty seeking, self-directedness and cooperativeness levels of business people in Yozgat province significant predictors of entrepreneurship orientations?

4) How do novelty seeking, self-directedness and cooperativeness levels of business people in Yozgat province affect the economic development of the province?

\section{METHODOLOGY}

This study, which examines the effect of temperament and characters of business people in Yozgat on entrepreneurship orientations and the economic development level of the province, is designed in correlational survey model which is one of the quantitative research models. Correlational survey model aims to determine the presence and / or degree of covariance between two and more variables (Karasar 2012).

\section{Universe and Sampling}

The universe of the research is consisted of business people operating in various sectors in Yozgat province in 2019. The study group consists of 224 business people selected from the universe using the convenience sampling method. 31 (14\%) of the participants are female and $193(86 \%)$ of them are male. The values regarding the personal information of the business people who make up the sample group are presented in Table 1.

Table 1. Frequency and percentage values of personal information

\begin{tabular}{|llll|}
\hline Variable & Groups & $f$ & $\%$ \\
\hline \multirow{3}{*}{ Gender } & Female & 31 & 14 \\
& Male & 193 & 86 \\
& Total & 224 & 100 \\
\hline \multirow{4}{*}{ Age } & 30 and below & 40 & 18 \\
& $31-40$ & 98 & 44 \\
& $41-50$ & 45 & 20 \\
& 50 and above & 41 & 18 \\
\multirow{4}{*}{ Task } & Total & 224 & 100 \\
& Manager & 121 & 54 \\
& Manager Assistant & 39 & 17 \\
\multirow{5}{*}{ Experience in the Sector } & 64 & 29 \\
& Employee & 224 & 100 \\
\hline & Total & 13 & 6 \\
& 1 year and less & 88 & 39 \\
& 2-10 years & 61 & 27 \\
& $11-15 y 1$ y & 26 & 12 \\
& $16-20$ years & 36 & 16 \\
\hline
\end{tabular}


International Journal of Business Management and Economic Review

Vol. 4, No. 03; 2021

ISSN: 2581-4664

\begin{tabular}{|c|c|c|c|}
\hline & Total & 224 & 100 \\
\hline \multirow{6}{*}{ Duration in the Institution } & 1 year and less & 22 & 10 \\
\hline & 2-10 years & 102 & 46 \\
\hline & $11-15$ years & 55 & 25 \\
\hline & $16-20$ years & 19 & 9 \\
\hline & 21 and over & 26 & 12 \\
\hline & Total & 224 & 100 \\
\hline \multirow{4}{*}{ Operation Period } & $1-5$ years & 45 & 20 \\
\hline & $6-10$ years & 51 & 23 \\
\hline & $11-15$ years & 63 & 28 \\
\hline & More than 15 years & 65 & 29 \\
\hline & Total & 224 & 100 \\
\hline \multirow{9}{*}{ Sector } & Mechanical / Boiler / Equipment & 15 & 7 \\
\hline & Metal Works & 17 & 8 \\
\hline & Furniture & 19 & 9 \\
\hline & Food & 67 & 30 \\
\hline & Plastic & 5 & 2 \\
\hline & Chemical Substances & 3 & 1 \\
\hline & Defense Industry & 3 & 1 \\
\hline & Other & 95 & 42 \\
\hline & Total & 224 & 100 \\
\hline \multirow{5}{*}{ Number of Employees } & $1-50$ people & 203 & 91 \\
\hline & $51-250$ & 16 & 7 \\
\hline & $251-500$ & 3 & 1 \\
\hline & 500 and above & 2 & 1 \\
\hline & Total & 224 & 100 \\
\hline \multirow{6}{*}{ General Success Situation } & Insufficient & 5 & 2 \\
\hline & Below mean & 14 & 6 \\
\hline & Mean & 118 & 53 \\
\hline & Above mean & 55 & 25 \\
\hline & High & 32 & 14 \\
\hline & Total & 224 & 100 \\
\hline \multirow{3}{*}{ Export Situation } & Yes & 20 & 9 \\
\hline & No & 204 & 91 \\
\hline & Total & 224 & 100 \\
\hline
\end{tabular}

\section{Data Collection Tools}

Novelty Seeking $($ Cronbach Alpha $=.74)$, Self-Directedness $($ Cronbach Alpha $=.83)$ and 


\section{International Journal of Business Management and Economic Review}

Vol. 4, No. 03; 2021

ISSN: 2581-4664

Cooperativeness (Cronbach Alpha $=.82$ ) scales of the Temperament and Character Inventory developed by Cloninger and adapted to Turkish by Köse and Sayar (2004) and Entrepreneurship Orientation Scale (Cronbach Alpha $=.92)$ which was developed by Tayauova (2009) was used in the research. Scales of Novelty Seeking, Self-Directedness and Cooperativeness are coded as 1 (true) and 0 (false); and Entrepreneurship Orientation Scale is coded as 1 (strongly disagree), 2 (disagree), 3 (uncertain), 4 (agree) and 5 (strongly agree). In addition, economic data of the Yozgat province, which was taken from the Turkey Statistical Institute (TUIK) (2020) website, have been used in the research.

\section{Transactions and Data Analysis}

Data collection tools were distributed by the researcher to 226 business people who voluntarily participated in the research. 2 of these scales filled out by participants were found to be missing or incorrect, so they were not included in the analysis. Thus, 224 responses of the business people were analyzed. The collected data were analyzed using SPSS 22.0 program. Firstly, the analyses were performed in order to find out whether the data met the one-way and multi-way normality assumptions. For this purpose, the skewness-kurtosis values of the data set were examined. It was concluded that the novelty seeking (.17 to .32), Self-Directedness (.43 to -.08), Cooperativeness (.26 to -.84) and Entrepreneurship Orientation (-.90 and .75) scores are within the limits of normal distribution. George and Mallery (2003) stated that if the skewness and kurtosis coefficients are between \pm 2 range, the data show normal distribution. Since multivariate analyzes are used in the study, it was also examined whether there was multicollinearity problem between variables. Therefore, the correlation values between the variables were examined. Correlation between the predictive variables above .80 indicates that there may be multicollinearity problems, and correlation above .90 indicates that there may be an important multicollinearity problem (Büyüköztürk 2011). Based on this information, as seen in Table 1, there is no multicollinearity problem between the sub-dimensions. In the analyses, the significance of the difference between the means was tested at .05 level. In the interpretation of arithmetic means, the followings were considered, the range 1.00-1.79 "very low", the range 1.80-2.59 "low", the range 2.60-3.39 "medium", the range 3.40-4.19 "high" and the range 4.205.00 "very high". Descriptive statistics, correlation and stepwise regression analyses were used.

\section{FINDINGS}

The arithmetic mean, standard deviation and skewness-kurtosis values related to the scales used in the study and the relationships between the scales are presented in Table 2.

Table 2. Descriptive statistics of the variables and correlation analysis findings

\begin{tabular}{|lcccl|}
\hline & Skewness Kurtosis $\overline{\mathrm{x}}$ & $\mathrm{SD}$ & $\begin{array}{l}\text { Entrepreneurship } \\
\text { Orientation }\end{array}$ & $\begin{array}{l}\text { Self } \\
\text { Directedness }\end{array}$ Cooperativeness \\
\hline $\begin{array}{l}\text { Entrepreneurship } \\
\text { Orientation }\end{array}$ & -.90 & .75 & 3.778 .041 & \\
Self Directedness & .17 & -.09 & $0.674 .72-.203^{* *}$ & 1
\end{tabular}




\section{International Journal of Business Management and Economic Review}

Vol. 4, No. 03; 2021

ISSN: $2581-4664$

\begin{tabular}{|c|c|c|c|c|c|}
\hline Cooperativeness & .33 & 1.74 & $0.724 .40-.060$ & $.450^{* * *}$ & 1 \\
\hline Novelty Seeking & .22 & -.05 & 0.574 .12 .016 & .021 & -.071 \\
\hline
\end{tabular}

${ }^{*} p<.05, * * p<.001 ; N=224$

As indicated in Table 2, the level of entrepreneurship orientations $(=3.80)$ of the business people participating in the research are high, self-directedness $(=0.67)$, cooperativeness $(=0.72)$ and novelty seeking $(=0.51)$ are above the mean. The effect of such a situation on the economic development of the city has been examined in line with some statistical data. Indeed, entrepreneurs are the main actors that are the engines of social development and their investments will undoubtedly be of great importance in the development of their regions. Considering these ideas, the gross domestic product (GDP), exports, imports and the number of entrepreneurs in the province, which are considered to be the primary economic indicators of the Yozgat province, were examined.

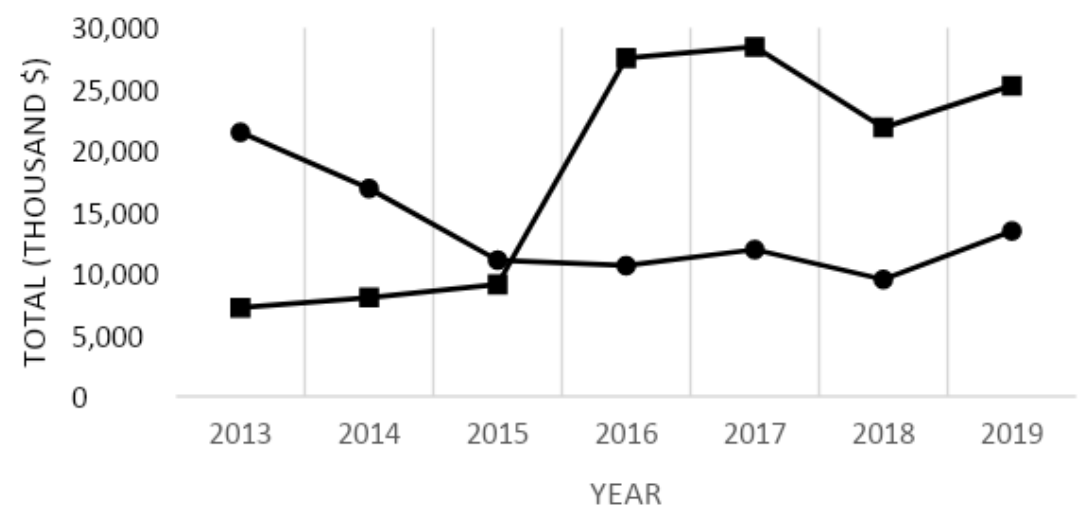

Figure 1. Gross domestic product amount of Yozgat province (2004-2018)

The gross domestic product, which is defined as the monetary equivalent of all goods and services that are not completed within a certain period of time within a country's economic unit or a foreign economic unit, is used to measure the welfare level of a society. In Figure 1, GDP figures of Yozgat between 2004 - 2018 years are illustrated with Turkey averages. Although Yozgat province GDP figures showed an upward trend, it is observed that it has a slower increase trend compared to country averages. Turkey is a developing country and steadily grew from 2004 to 2018. Although the targeted growth could not be reached due to the global economic changes in 2018, the growth trend was caught again in 2019. On the other hand, the GDP figures of Yozgat province steadily moved away from the country's average in the 14-year period, so it did not show a development equivalent to the growth of the country. Considering the ranking in 81 provinces, Yozgat fell from 35th to 48th in this 14-year period. 


\section{International Journal of Business Management and Economic Review}

Vol. 4, No. 03; 2021

ISSN: 2581-4664

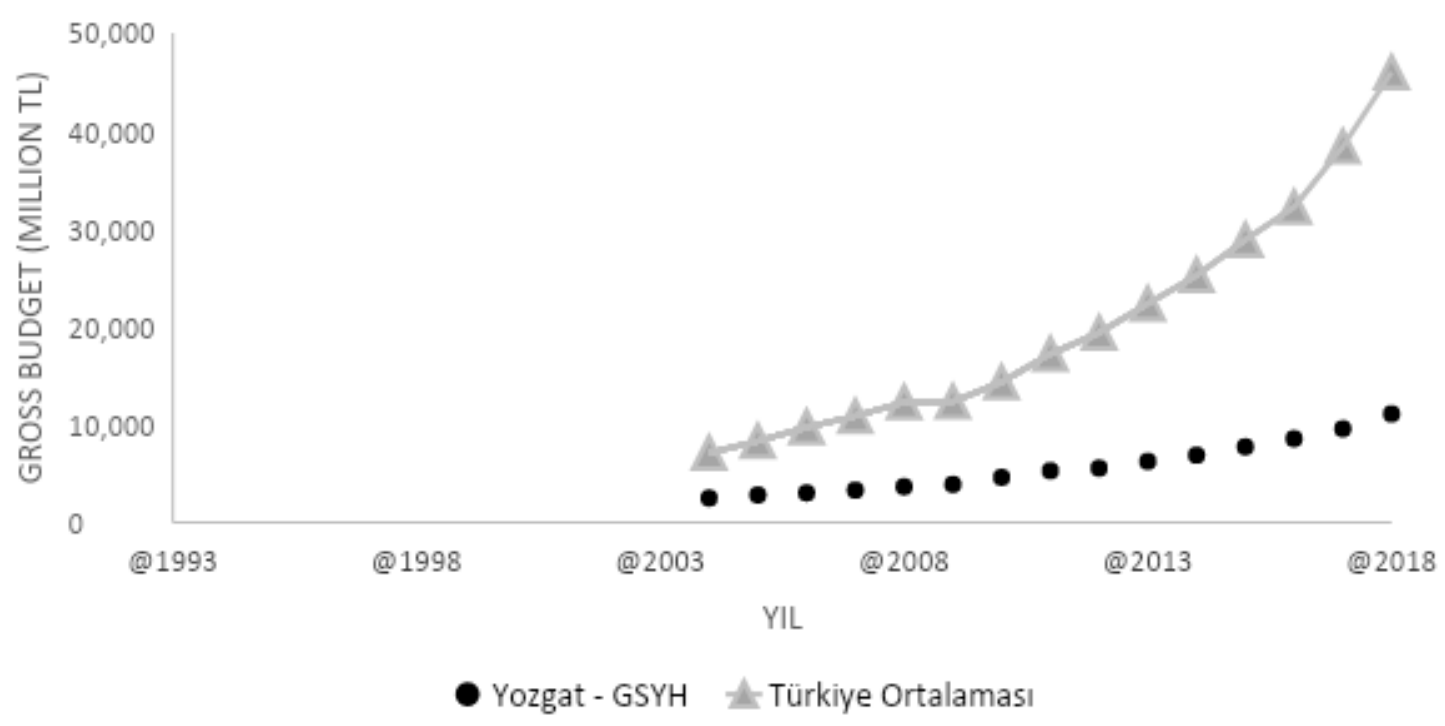

Figure 2. Import and export amounts of Yozgat province (2012-2019)

The amount of export is one of the most important indicators about the amount of production in a country or city. However, the export figures at this stage should be studied together with import figures as well as Turkey's average. Although the export amounts show the amount of production activities in a place, this can never reveal the development of the province alone. In this context, the export amounts of Yozgat province are presented in Figure 2. As indicated in Figure 2, it is seen that export figures show a decreasing trend while import figures show an upward trend. Especially between 2018-2019, the import and export figures increased in parallel. Based on these figures, it can be concluded that the imported products are not used for the purpose of producing new products and presenting them to the foreign market, but for the purpose of producing retail products or products for the domestic market.

Import and export figures between 2013-2019 years are given in Table 3 including Turkey's averages. Yozgat has a well performance below the national average in both the import and export figures. Considering the export figures, Yozgat fell to 73th in 2019 from 70th in 2013 in 81 provinces. Similarly, while its share in country's total exports was 0.013 (13 per thousand) in 2013, its share in total exports fell by $44 \%$ in 2019 to 0.007 ( 7 per thousand). If the development of the export of the province is accepted as an indicator of the production capacity in the province and the developing industry, it can be said that the development of Yozgat is rather slow and it steadily strengthens its position below the country average in 81 provinces. This situation is also an indicator that the level of entrepreneurship in the province is not at a sufficient level.

Table 3. Export-import figures between 2013-2019 (million \$)

Yozgat Import Import Turkey Average Yozgat Export Turkey Average 


\section{International Journal of Business Management and Economic Review}

Vol. 4, No. 03; 2021

ISSN: 2581-4664

\begin{tabular}{|llllll|}
\hline \hline & \multicolumn{3}{l|}{ Export } \\
\cline { 2 - 6 } & 2013 & 7.22 & 3220.03 & 21.50 & 1993.59 \\
2014 & 8.05 & 3100.52 & 16.92 & 2055.62 \\
2015 & 9.11 & 2637.27 & 11.09 & 1863.98 \\
2016 & 27.54 & 2496.16 & 10.65 & 1842.56 \\
2017 & 28.45 & 2947.10 & 11.95 & 2030.80 \\
2018 & 21.88 & 2853.73 & 9.52 & 2187.27 \\
2019 & 25.30 & 2596.88 & 13.47 & 2232.97 \\
\hline
\end{tabular}

The total number of enterprises in Yozgat between 2008 and 2018 published on TUIK's website supports this idea.

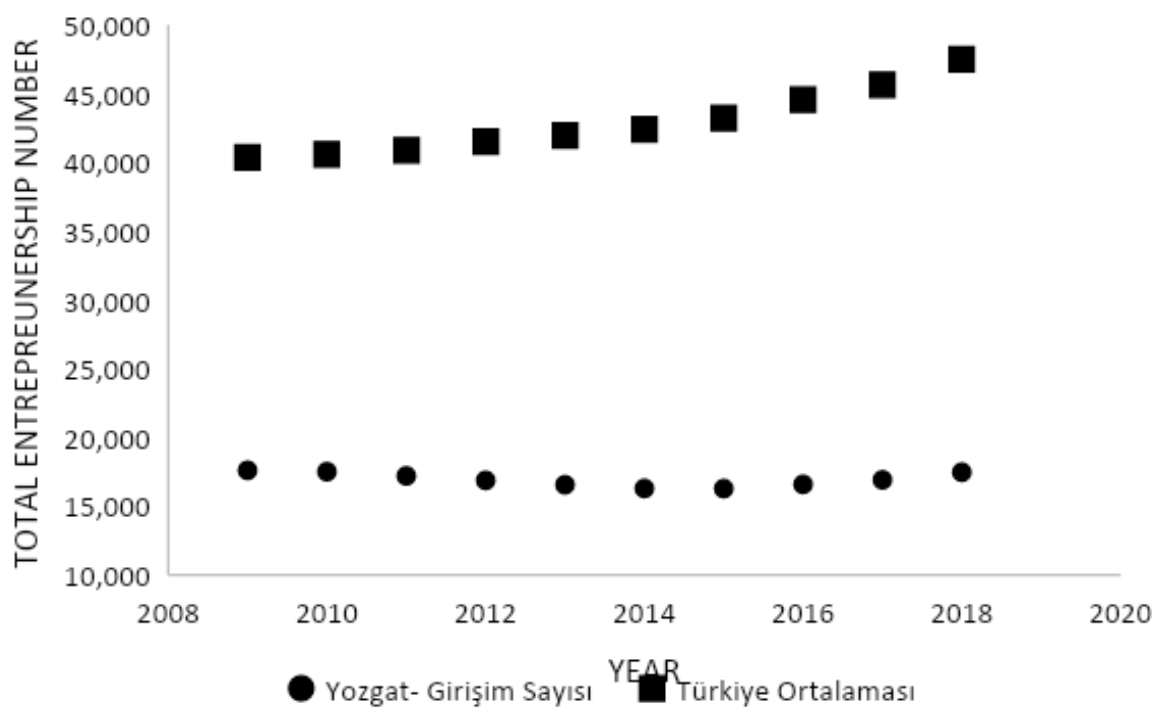

Figure 3. Total number of enterprises in Yozgat province (2013-2017)

Figure 3 shows the total number of enterprises in Yozgat. Between 2009 and 2018, the number of enterprises in the province decreased until 2014, and since 2014 it has reached a steady upward trend. The number of enterprises has increased significantly since 2014 and has reached its value in 2009. The total number of entrepreneurs in the province is far below the country average and the difference is steadily increasing. On the other hand, it can be inferred that the increase in exports especially in 2019 is supported by the increase of new enterprises. It is considered that the entrepreneurial personality traits of business people in Yozgat have an impact on such an increase.

Independent group $t$ test was performed to determine whether the entrepreneurship orientation scale scores of the business people who make up the sample group and temperament and character traits scale scores differentiate according to the gender variable.

Table 3. Independent group t test results, performed to determine whether the entrepreneurship orientation scale scores of the business people and temperament and character traits scale scores 


\section{International Journal of Business Management and Economic Review}

Vol. 4, No. 03; 2021

ISSN: 2581-4664

differentiate according to the gender variable

\begin{tabular}{|c|c|c|c|c|c|c|c|c|}
\hline \multirow{2}{*}{ Score } & \multirow{2}{*}{ Groups } & \multirow{2}{*}{$n$} & \multirow{2}{*}{$\overline{\mathrm{x}}$} & \multirow{2}{*}{$s S$} & \multirow{2}{*}{$\mathrm{Sh}_{\overline{\mathrm{x}}}$} & \multicolumn{3}{|c|}{ Test $t$} \\
\hline & & & & & & $t$ & $S d$ & $p$ \\
\hline \multirow{2}{*}{ Entrepreneurship Orientation } & Male & 193 & 45.24 & 8.09 & .58 & \multirow{2}{*}{-.24} & \multirow{2}{*}{222} & \multirow{2}{*}{.81} \\
\hline & Female & 31 & 45.62 & 7.84 & 1.41 & & & \\
\hline \multirow{2}{*}{ Novelty Seeking } & Male & 193 & 22.80 & 4.19 & .30 & \multirow{2}{*}{.56} & \multirow{2}{*}{222} & \multirow{2}{*}{.58} \\
\hline & Female & 31 & 22.35 & 3.71 & .67 & & & \\
\hline \multirow{2}{*}{ Self Directedness } & Male & 193 & 29.25 & 4.64 & .33 & \multirow{2}{*}{-.47} & \multirow{2}{*}{222} & \multirow{2}{*}{.64} \\
\hline & Female & 31 & 29.68 & 5.24 & .94 & & & \\
\hline \multirow{2}{*}{ Cooperativeness } & Male & 193 & 30.35 & 4.41 & .32 & \multirow{2}{*}{-.50} & \multirow{2}{*}{222} & \multirow{2}{*}{.62} \\
\hline & Female & 31 & 30.77 & 4.33 & .78 & & & \\
\hline
\end{tabular}

As seen in Table 3, as a result of conducted independent groups t test, any significant difference by gender variable has not been found between the arithmetic means of the groups for entrepreneurship orientation $(\mathrm{t}=-.24 ; \mathrm{p} .05)$, novelty seeking $(\mathrm{t}=.56 ; \mathrm{p} .05)$, self-directedness $(\mathrm{t}=-.47 ; \mathrm{p} .05)$ and cooperativeness $(t=-.50 ; p$.05) scales scores of business people.

One-way analysis of variance (ANOVA) test was performed to determine whether the entrepreneurship orientation scale scores of the business people who make up the sample group and temperament and character traits scale scores differentiate according to the age variable.

Table 4. One way analysis of variance (ANOVA) test results, performed to determine whether the entrepreneurship orientation scale scores of the business people and temperament and character traits scale scores differentiate according to the age variable

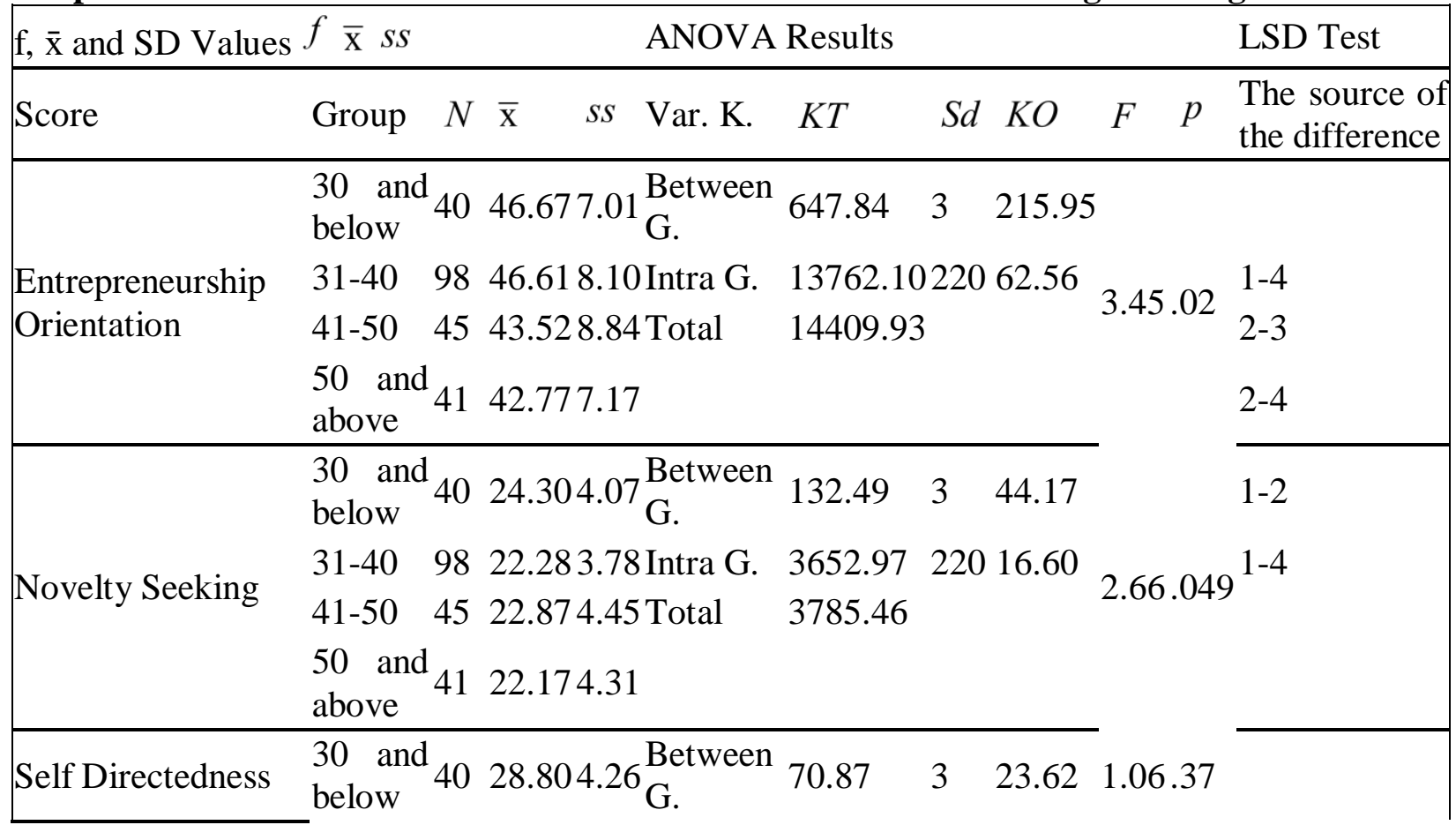




\section{International Journal of Business Management and Economic Review}

Vol. 4, No. 03; 2021

ISSN: 2581-4664

\begin{tabular}{|c|c|c|c|c|}
\hline & $\begin{array}{lll}31-40 & 98 & 29.074 .82 \text { Intra G. } \\
41-50 & 45 & 29.224 .87 \text { Total } \\
\begin{array}{l}50 \text { and } \\
\text { above }\end{array} & 31 & 30.464 .69 \\
\end{array}$ & $\begin{array}{l}4886.87 \\
4957.75\end{array}$ & 22322.21 & \\
\hline Cooperativeness & 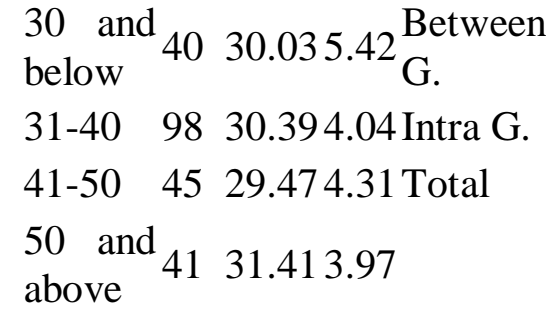 & $\begin{array}{l}134.39 \\
4175.83 \\
4310.21\end{array}$ & $\begin{array}{lr}3 & 44.80 \\
220 & 18.99\end{array}$ & 2.36 .07 \\
\hline
\end{tabular}

As indicated in Table 4, as a result of one-way analysis of variance (ANOVA), the difference between the arithmetic means of the groups for self-directedness $(F=1.06 ; p>.05)$ and cooperativeness $(F=2.36 ; p>.05)$ scales was not found significant, but the difference between the arithmetic means of the groups for entrepreneurship orientation $(F=3.45 ; \mathrm{p}<.05)$ and novelty seeking $(\mathrm{F}=2.66 ; \mathrm{p}<.05)$ scales was found significant. Complementary analysis (post hoc) was carried out to determine from which groups the significant difference determined for the entrepreneurship orientation scale and the novelty seeking scale scores was caused. For this purpose, first of all, the homogeneity of the variances was examined utilizing Levene analysis, and it was found that the variances were homogeneous $(L F=.850 ; p>, 05 / L F=.420 ; p>, 05)$. Thus, LSD test was preferred. As a result of the LSD test, the significant difference was found to be realized for the entrepreneurship orientation scale, at $\mathrm{p}<.05$ level in favor of the aged 30 and under between the aged 30 and under and the aged 50 and over; at $p<.05$ level in favor of the aged 31-40 between the aged 31-40 and the aged 41-50; at $p<.05$ level in favor of the aged 31-40 between the aged 31-40 and the aged 50 and above. The differences between the means of other groups were not significant ( $p>.05$ ). Findings show that entrepreneurship orientation of young business people is higher compared to business people over 50 years old.

One-way analysis of variance (ANOVA) test was performed to determine whether the entrepreneurship orientation scale scores of the business people who make up the sample group and temperament and character traits scale scores differentiate according to the task variable.

Table 5. One way analysis of variance (ANOVA) test results, performed to determine whether the entrepreneurship orientation scale scores of the business people and temperament and character traits scale scores differentiate according to the task variable

\begin{tabular}{|c|c|c|c|c|c|c|c|c|c|}
\hline $\mathrm{f}, \overline{\mathrm{x}}$ and SD Values & & & & & ANOVA & esults & & & \\
\hline Score & Group & $N$ & $\overline{\mathrm{x}}$ & $s s$ & Var. K. & KT & $S d$ & $\mathrm{KO}$ & $F$ \\
\hline \multirow{2}{*}{$\begin{array}{l}\text { Entrepreneurship } \\
\text { Orientation }\end{array}$} & Manager & 121 & 44.9 & 7.8 & $\begin{array}{l}\text { Between } \\
\text { G. }\end{array}$ & 297.88 & 2 & 148.93 & \multirow{2}{*}{2.33 .10} \\
\hline & $\begin{array}{l}\text { Manager } \\
\text { Assistant }\end{array}$ & 39 & 47.7 & 7.5 & Intra G. & 14112.0 & 7221 & 63.86 & \\
\hline
\end{tabular}




\section{International Journal of Business Management and Economic Review}

Vol. 4, No. 03; 2021

ISSN: 2581-4664

\begin{tabular}{|c|c|c|c|c|c|}
\hline & Employee & 64 44.44 8.55 Total & 14409.93 & & \\
\hline \multirow{3}{*}{ Novelty Seeking } & Manager & 12122.834 .04 G. & 2.54 & 1.27 & \multirow{3}{*}{$.07 \quad .93$} \\
\hline & $\begin{array}{l}\text { Manager } \\
\text { Assistant }\end{array}$ & 39 22.62 3.94 Intra G. & 3782.93 & \multirow[t]{2}{*}{22117.12} & \\
\hline & Employee & 64 22.634.43 Total & 3785.46 & & \\
\hline \multirow{3}{*}{ Self Directedness } & Manager & $12129.414 .87_{\text {G. }}^{\text {Between }}$ & 51.16 & 25.58 & \multirow{3}{*}{1.15 .32} \\
\hline & $\begin{array}{l}\text { Manager } \\
\text { Assistant }\end{array}$ & 39 28.31 4.51 Intra G. & 4906.58 & 22122.20 & \\
\hline & Employee & $\begin{array}{ll}64 & 29.714 .52 \text { Total } \\
\end{array}$ & 4957.75 & & \\
\hline \multirow{3}{*}{ Cooperativeness } & Manager & 12130.704 .02 G. & 56.27 & 28.14 & \multirow{3}{*}{1.46 .23} \\
\hline & $\begin{array}{l}\text { Manager } \\
\text { Assistant }\end{array}$ & 39 29.33 4.09 Intra G. & 4253.94 & 22119.25 & \\
\hline & Employee & 64 30.525.16 Total & 4310.21 & & \\
\hline
\end{tabular}

As seen in Table 5, as a result of one-way analysis of variance (ANOVA), the difference between the arithmetic means of the groups was not found significant for entrepreneurship orientation $(\mathrm{F}=2.33$; $\mathrm{p}>05)$ and novelty seeking $(\mathrm{F}=.07 ; \mathrm{p}>.05)$, self-directedness $(\mathrm{F}=1.15 ; \mathrm{p}>.05)$ and cooperativeness $(\mathrm{F}=1.46 ; \mathrm{p}>$.05) scales. One way analysis of variance (ANOVA) test was performed to determine whether the entrepreneurship orientation scale scores of the business people who make up the sample group and temperament and character traits scale scores differentiate according to the experience in the sector variable.

Table 6. One way analysis of variance (ANOVA) test results, performed to determine whether the entrepreneurship orientation scale scores of the business people and temperament and character traits scale scores differentiate according to the experience in the sector variable

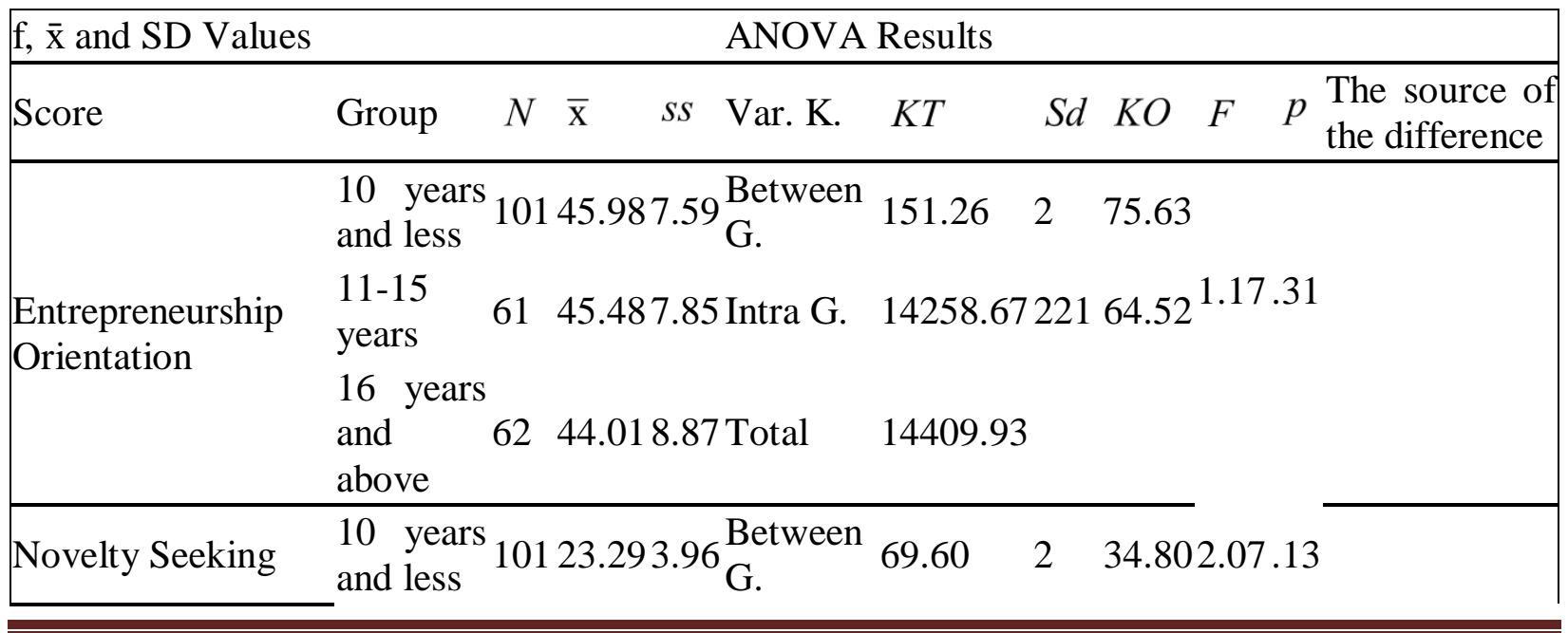




\section{International Journal of Business Management and Economic Review}

Vol. 4, No. 03; 2021

ISSN: 2581-4664

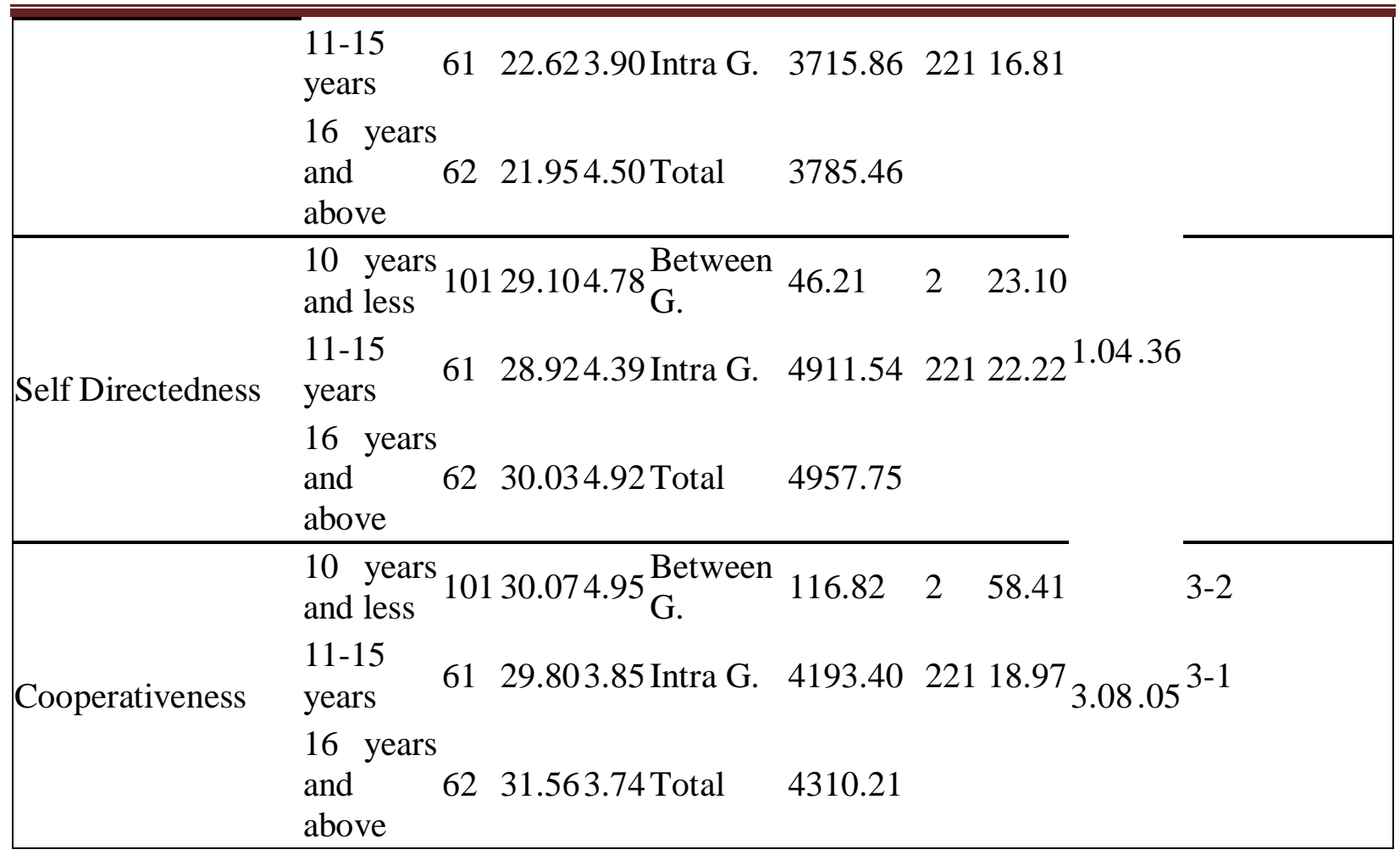

As indicated in Table 6, as a result of one-way analysis of variance (ANOVA), the difference between the arithmetic means of the groups for entrepreneurship orientation $(F=1.17 ; p>.05)$, novelty seeking $(\mathrm{F}=2.07 ; \mathrm{p}>.05)$ and self-directedness $(\mathrm{F}=1.04 ; \mathrm{p}>.05)$ scales was not found significant, but the difference between the arithmetic means of the groups for cooperativeness $(F=3.08 ; p<.05)$ scale was found significant. Complementary analysis (post hoc) was carried out to determine from which groups the significant difference determined for the cooperativeness scale scores was caused. For this purpose, first of all, the homogeneity of the variances was examined using Levene analysis and it was found that the variances were homogeneous $(\mathrm{LF}=3.02 ; \mathrm{p}>.05)$. Thus, LSD test was preferred. As a result of the LSD test, it has been determined that the significant difference has been realized for cooperativeness scale at the level of $\mathrm{p}<.05$ in favor of employees who have been working for 16 years and above, between employees who have been working for 16 years and above, 11-15 years and 10 years and below. The differences between the means of other groups were not significant ( $p>$ $.05)$. Findings according to experience variable show that employees who have been working for 16 years and above are more likely to cooperativeness compared to employees who have been working for shorter period.

One way analysis of variance (ANOVA) test was performed to determine whether the entrepreneurship orientation scale scores of the business people who make up the sample group and temperament and character traits scale scores differentiate according to the variable of working time in their institutions.

Table 7. One way analysis of variance (ANOVA) test results, performed to determine whether the entrepreneurship orientation scale scores of the business people and temperament and character traits scale scores differentiate according to the variable of working time in their institutions 


\section{International Journal of Business Management and Economic Review}

Vol. 4, No. 03; 2021

ISSN: 2581-4664

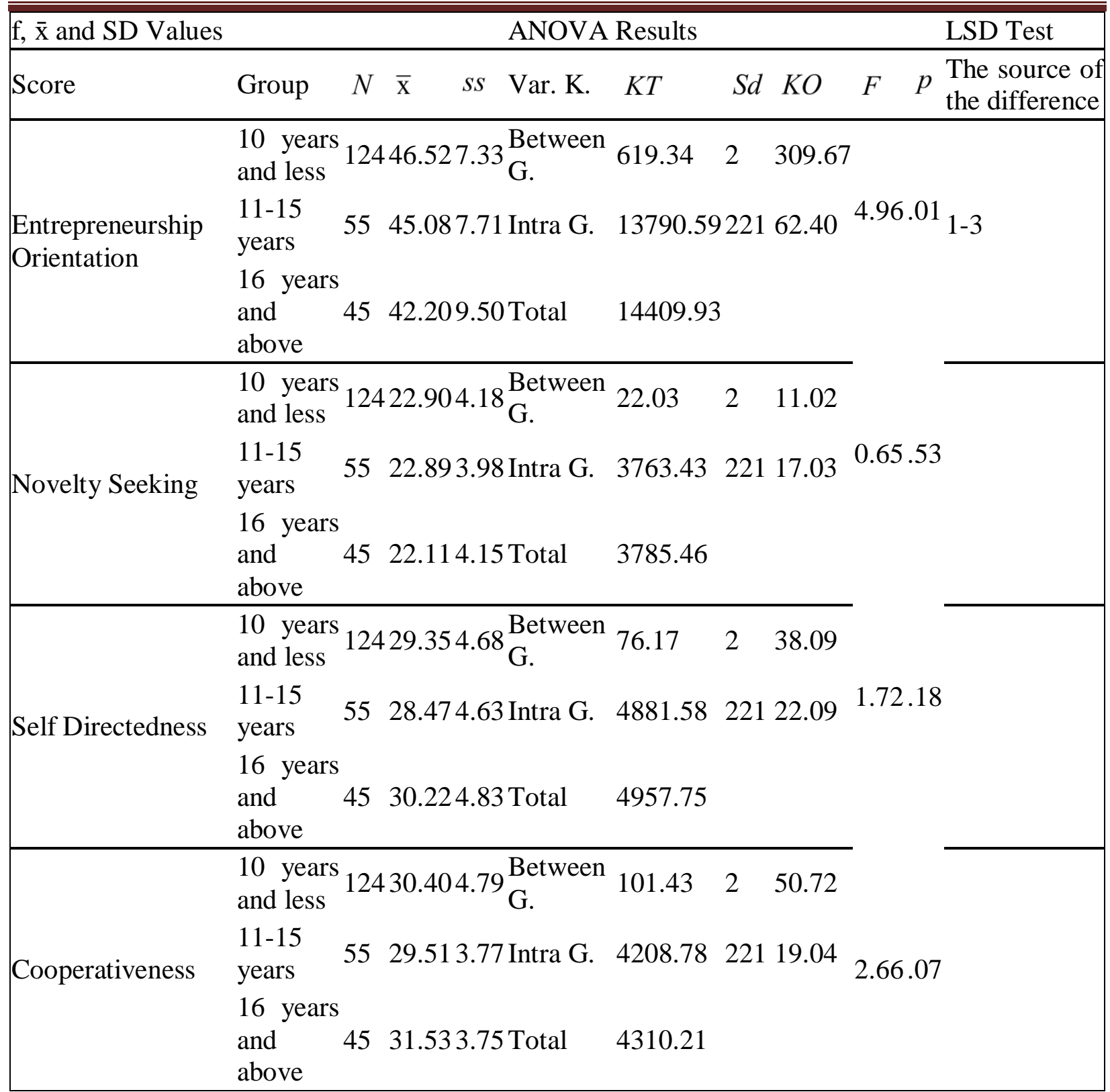

As seen in Table 7, as a result of one-way analysis of variance (ANOVA), the difference between the arithmetic means of the groups for cooperativeness $(F=2.66 ; p>.05)$, novelty seeking $(F=.65 ; p>.05)$ and self-directedness $(F=1.72 ; p>05)$ scales was not found significant, but the difference between the arithmetic means of the groups for entrepreneurship orientation $(F=4.96 ; p<.05)$ scale was found significant. Complementary analysis (post hoc) was carried out to determine from which groups the significant difference determined for the entrepreneurship orientation scale score was caused. For this purpose, first of all, the homogeneity of the variances was examined by Levene analysis and it was found that the variances were homogeneous $(L F=1.62 ; p>, 05)$. Thus, LSD test was preferred. As a result of the LSD test, it has been determined that the significant difference has been realized for cooperativeness scale at the level of $\mathrm{p}<.05$ in favor of those who have been working for 10 years and 


\section{International Journal of Business Management and Economic Review}

Vol. 4, No. 03; 2021

ISSN: 2581-4664

less, between who have been working for 10 years and less and 16 years and above. The differences between the means of other groups were not significant ( $p>.05)$. As a result, the entrepreneurship orientation of those with 10 years or less working time in the company is higher than those with 16 years or more.

One way analysis of variance (ANOVA) test was performed to determine whether the entrepreneurship orientation scale scores of the business people who make up the sample group and temperament and character traits scale scores differentiate according to the variable of operation period of institutions.

Table 8. One way analysis of variance (ANOVA) test results, performed to determine whether the entrepreneurship orientation scale scores of the business people and temperament and character traits scale scores differentiate according to the variable of operation period of institutions

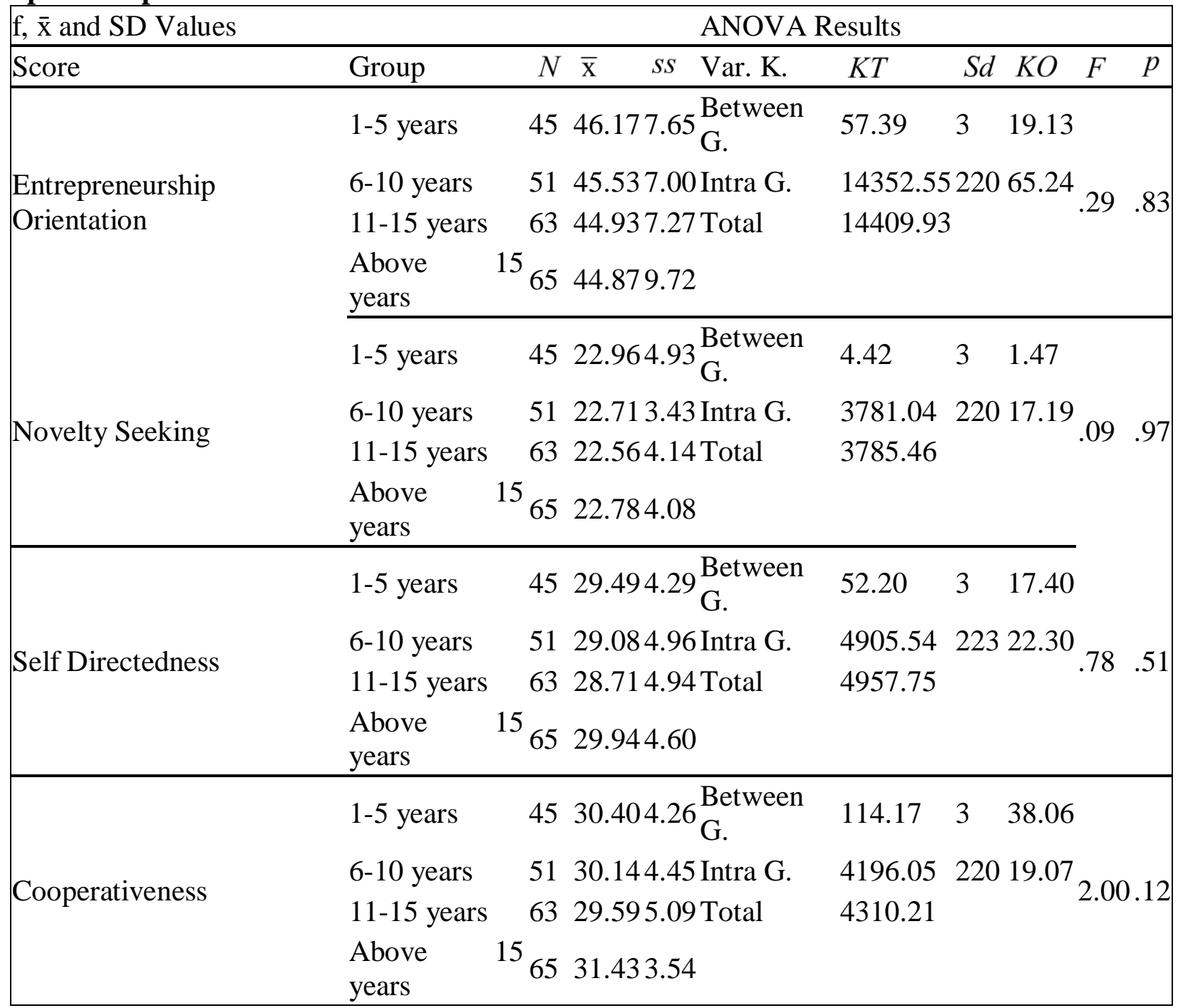

As indicated in Table 8, as a result of one-way analysis of variance (ANOVA), the difference 


\section{International Journal of Business Management and Economic Review}

Vol. 4, No. 03; 2021

ISSN: 2581-4664

between the arithmetic means of the groups was not found significant for entrepreneurship orientation $(F=.29 ; \quad p>.05)$ and novelty seeking $(F=.09 ; \quad p>.05)$, self-directedness $(F=.78 ; p>.05)$ and cooperativeness $(F=2.00 ; p>.05)$ scales.

Kruskal Wallis-H Test was performed to determine whether the entrepreneurship orientation scale scores of the business people who make up the sample group and temperament and character traits scale scores differentiate according to the variable of sector they work in.

Table 9. Kruskal Wallis-H test results, performed to determine whether the entrepreneurship orientation scale scores of the business people and temperament and character traits scale scores differentiate according to variable of the sector they work in

\begin{tabular}{|c|c|c|c|c|c|c|c|}
\hline Score & Groups & & $N$ & $\bar{x}_{\text {sira }}$ & $x^{2}$ & $s d$ & $p$ \\
\hline \multirow{8}{*}{$\begin{array}{l}\text { Entrepreneurship } \\
\text { Orientation }\end{array}$} & $\begin{array}{l}\text { Mechanical / Boiler } \\
\text { Equinment }\end{array}$ & I & 15 & 132.47 & \multirow{8}{*}{5.65} & \multirow{8}{*}{7} & \multirow{8}{*}{.59} \\
\hline & Metal Works & & 17 & 111.41 & & & \\
\hline & Furniture & & 19 & 119.84 & & & \\
\hline & Food & & 67 & 121.51 & & & \\
\hline & Plastic & & 5 & 106.60 & & & \\
\hline & Chemical Substances & & 3 & 109.67 & & & \\
\hline & Defense Industry & & 3 & 121.00 & & & \\
\hline & Other & & 95 & 101.85 & & & \\
\hline \multirow{8}{*}{ Novelty Seeking } & $\begin{array}{l}\text { Mechanical / Boiler } \\
\text { Equipment }\end{array}$ & I & 15 & 100.53 & \multirow{8}{*}{8.35} & \multirow{8}{*}{7} & \multirow{8}{*}{.31} \\
\hline & Metal Works & & 17 & 92.53 & & & \\
\hline & Furniture & & 19 & 114.42 & & & \\
\hline & Food & & 67 & 115.34 & & & \\
\hline & Plastic & & 5 & 71.80 & & & \\
\hline & Chemical Substances & & 3 & 137.33 & & & \\
\hline & Defense Industry & & 3 & 51.00 & & & \\
\hline & Other & & 95 & 118.88 & & & \\
\hline \multirow{8}{*}{ Self Directedness } & $\begin{array}{l}\text { Mechanical / Boiler } \\
\text { Equipment }\end{array}$ & I & 15 & 88.50 & \multirow{8}{*}{5.79} & \multirow{8}{*}{7} & \multirow{8}{*}{.57} \\
\hline & Metal Works & & 17 & 117.32 & & & \\
\hline & Furniture & & 19 & 105.95 & & & \\
\hline & Food & & 67 & 108.90 & & & \\
\hline & Plastic & & 5 & 125.40 & & & \\
\hline & Chemical Substances & & 3 & 158.17 & & & \\
\hline & Defense Industry & & 3 & 79.33 & & & \\
\hline & Other & & 95 & 118.21 & & & \\
\hline \multirow{2}{*}{ Cooperativeness } & $\begin{array}{lll}\text { Mechanical } & / & \text { Boiler } \\
\text { Equipment } & & \end{array}$ & I & 15 & 117.17 & \multirow{2}{*}{2.09} & \multirow{2}{*}{7} & \multirow{2}{*}{.96} \\
\hline & Metal Works & & 17 & 116.88 & & & \\
\hline
\end{tabular}




\section{International Journal of Business Management and Economic Review}

Vol. 4, No. 03; 2021

ISSN: 2581-4664

\begin{tabular}{|lll|}
\hline \hline Furniture & 19 & 97.79 \\
Food & 67 & 114.17 \\
Plastic & 5 & 122.10 \\
Chemical Substances & 3 & 143.83 \\
Defense Industry & 3 & 119.50 \\
Other & 95 & 111.03 \\
\hline
\end{tabular}

As seen in Table 9, as a result of the Kruskal Wallis-H Test conducted to determine whether business peoples' who make up the sample group entrepreneurship orientation $\left(x^{2}=5.65 ; \mathrm{p} .05\right)$, novelty seeking $\left(\mathrm{x}^{2}=8.35 ; \mathrm{p} .05\right)$, self-directedness $\left(\mathrm{x}^{2}=5.79 ; \mathrm{p} .05\right)$ and cooperativeness $\left(\mathrm{x}^{2}=2.09 ; \mathrm{p} .05\right)$ scores of the scales differentiate significantly according to the variable of sector they work in the differences between the mean ranks of the groups were not found significant.

Mann Whitney-U test was performed to determine whether the entrepreneurship orientation scale scores of the business people who make up the sample group and temperament and character traits scale scores differentiate according to the variable of the number of employees in their workplace.

Table 10. Mann Whitney-U test results, performed to determine whether the entrepreneurship orientation scale scores of the business people and temperament and character traits scales scores differentiate according to the variable of the number of employees

\begin{tabular}{|llllllll|}
\hline Score & Groups & $N$ & $\bar{x}_{\text {sira }}$ & $\sum_{\text {sira }}$ & $U$ & $z$ & $p$ \\
\hline \multirow{3}{*}{ Entrepreneurship Orientation } & 50 and below & 203 & 109.95 & 22319.50 & & & \\
& 50 and above & 21 & 137.17 & 2880.50 & 1613.50 & $-1,834$ & .07 \\
& Total & 224 & & & & & \\
\hline \multirow{3}{*}{ Novelty Seeking } & 50 and below & 203 & 113.13 & 22965.00 & & & \\
& 50 and above & 21 & 106.43 & 2235.00 & 2004.00 & -.452 & .65 \\
\hline \multirow{3}{*}{ Self Directedness } & Total & 224 & & & & & \\
& 50 and below & 203 & 112.09 & 22754.00 & & & \\
& 50 and above & 21 & 116.48 & 2446.00 & 2048.00 & -.296 & .77 \\
Cooperativeness & Total & 224 & & & & & \\
& 50 and below & 203 & 111.82 & 22699.00 & & & \\
& 50 and above & 21 & 119.10 & 2501.00 & 1993.00 & -.491 & .62 \\
\hline
\end{tabular}

As seen in Table 10, as a result of the Mann Whitney-U Test conducted to determine whether business people's entrepreneurship orientation $(z=-1.86 ; p>.05)$, novelty seeking $(z=-.45 ; p>.05)$, selfdirectedness $(\mathrm{z}=-.30 ; \mathrm{p}>.05)$ and cooperativeness $(\mathrm{z}=-.49 ; \mathrm{p}>.05)$ scores of the scales differentiate significantly according to the variable of the number of employee in workplace the differences between the mean ranks were not found significant. Kruskal Wallis-H Test was performed to determine whether the entrepreneurship orientation scale scores of the business people and temperament and character traits scale scores differentiate according to the variable of the success of the institution they work for. 


\section{International Journal of Business Management and Economic Review}

Vol. 4, No. 03; 2021

ISSN: 2581-4664

Table 11. Kruskal Wallis-H Test results, performed to determine whether the entrepreneurship orientation scale scores of the business people and temperament and character traits scale scores differentiate according to the variable of the success of the institution they work for

\begin{tabular}{|lllllll|}
\hline Score & Groups & $N$ & $\bar{x}_{\text {sira }}$ & $x^{2}$ & $s d$ & $p$ \\
\hline \multirow{3}{*}{ Entrepreneurship Orientation } & Below mean & 19 & 93.18 & & & \\
& Mean & 118 & 103.39 & .01 & 2 & .01 \\
& Above mean & 87 & 129.08 & & & \\
& Below mean & 19 & 107.11 & & & \\
\multirow{3}{*}{ Novelty Seeking } & Mean & 118 & 120.50 & .14 & 2 & .14 \\
& Above mean & 87 & 102.83 & & & \\
\hline \multirow{3}{*}{ Self Directedness } & Below mean & 19 & 135.76 & & & \\
& Mean & 118 & 105.09 & .10 & 2 & .10 \\
& Above mean & 87 & 117.47 & & & \\
\hline \multirow{3}{*}{ Cooperativeness } & Below mean & 19 & 132.37 & & & \\
& Mean & 118 & 108.38 & .32 & 2 & .32 \\
& Above mean & 87 & 113.75 & & & \\
\hline
\end{tabular}

As indicated in Table 11, as a result of the Kruskal Wallis-H Test conducted to determine whether business people's who make up the sample group novelty seeking $\left(x^{2}=.14 ; p .05\right)$, selfdirectedness $\left(\mathrm{x}^{2}=.10 ; \mathrm{p} .05\right)$ and cooperativeness $\left(\mathrm{x}^{2}=.32 ; \mathrm{p} .0 .05\right)$ scores of the scales differentiate significantly according to the variable of the general success situation of the institution they work for the differences between the mean ranks of the groups were not found significant, but the scores of the entrepreneurship orientation $\left(\mathrm{x}^{2}=.01 ; \mathrm{p} .05\right)$ scale show a significant difference according to the variable of the general success situation of the institution they work for. Since there is no special method to determine from which groups the difference was caused, the groups were compared in pairs between each other with Mann Whitney-U analysis.

Table 12. Mann Whitney $U$ test results, performed to determine the groups which entrepreneurship orientation scale scores differentiate between according to the variable of the general success situation

\begin{tabular}{|llll|}
\hline Groups & Below mean & Mean & Above mean \\
\hline Below mean & $\mathrm{x}$ rank $=93.18$ & $\mathrm{p}>.05$ & $\mathrm{p}<.05$ \\
Mean & & $\mathrm{x}$ rank=103.39 & $\mathrm{p}<.05$ \\
Above mean & & & $\mathrm{x} \mathrm{rank=129.08}$ \\
\hline
\end{tabular}

As seen in Table 12, as a result of Mann Whitney-U analysis, performed to determine the groups which entrepreneurship orientation scale scores differentiate between business people who make up the sample group; such differentiation is determined to happen at $p<.05$ level in favor of the group of which general success is above the mean between the group of which general success situation is below the mean and the group of which general success is above the mean; at $p<.05$ level 


\section{International Journal of Business Management and Economic Review}

Vol. 4, No. 03; 2021

ISSN: 2581-4664

in favor of the group of which general success is above the mean between the group of which general success situation is the mean and the group of which general success is above the mean. The differences between the mean rank of the other groups were not significant ( $p>.05$ ).

Mann Whitney-U test was performed to determine whether the entrepreneurship orientation scale scores of the business people who make up the sample group and temperament and character traits scale scores differentiate according to the variable of the export situation of their workplace.

Table 13. Mann Whitney-U test results, performed to determine whether the entrepreneurship orientation scale scores of the business people and temperament and character traits scales scores differentiate according to the variable of the export situation

\begin{tabular}{|llllllll|}
\hline Score & Groups & $N$ & $\bar{x}_{\text {sira }}$ & $\sum_{\text {sira }}$ & $U$ & $z$ & $p$ \\
\hline \multirow{3}{*}{ Entrepreneurship Orientation } & Yes & 20 & 83.03 & 1660.50 & & & \\
& No & 204 & 115.39 & 23539.50 & 1450.50 & -2.13 & .03 \\
& Total & 224 & & & & & \\
\hline \multirow{3}{*}{ Novelty Seeking } & Yes & 20 & 96.58 & 1931.50 & & & \\
& No & 204 & 114.06 & 23268.50 & 1721.50 & -1.16 & .25 \\
& Total & 224 & & & & & \\
\hline \multirow{3}{*}{ Self Directedness } & Yes & 20 & 124.08 & 2481.50 & & & \\
& No & 204 & 111.37 & 22718.50 & 1808.50 & -.84 & .40 \\
& Total & 224 & & & & & \\
\hline \multirow{3}{*}{ Cooperativeness } & Yes & 20 & 140.18 & 2803.50 & & & \\
& No & 204 & 109.79 & 22396.50 & 1486.50 & -2.01 & .045 \\
& Total & 224 & & & & & \\
\hline
\end{tabular}

As indicated in Table 13, as a result of the Mann Whitney-U Test conducted to determine whether business people's entrepreneurship orientation $(z=-2.13 ; p>.05)$ and cooperativeness $(z=-2.01$; $\mathrm{p}>.05)$ scores of the scales differentiate significantly according to the variable of the export situation of workplace the differences between the means rank were found significant. This difference was realized in favor of non-exporters for entrepreneurship orientation scores; and in favor of the exporters for cooperativeness scores. As a result of the Mann Whitney-U Test conducted to determine whether novelty seeking $(\mathrm{z}=-1.16 ; \mathrm{p}>.05)$ and self-directedness $(\mathrm{z}=-.84 ; \mathrm{p}>.05)$ scores of the scales differentiate significantly according to the variable of the export situation of workplace, the differences between the means rank were not found significant. On the other hand, as a result of the correlation analysis conducted in line with the scores received by the business people in Yozgat with the answers given to the scales (Table 2), a negative, low level and significant relationship $(r=-.203 ; \mathrm{p}<.001)$ between entrepreneurship orientation and self-directedness; a moderate and significant relationship $(r=.450 ; p$ .001) between self-directedness and cooperativeness were found (Köklü, Büyüköztürk, \& Bökeoğlu, 2006). No significant relationship could be detected between other variables. The predictive power of the relationship between the predictive variables (self-directedness and novelty seeking) and the predicted variable (entrepreneurship orientation), which were found to have a significant relationship, 


\section{International Journal of Business Management and Economic Review}

Vol. 4, No. 03; 2021

ISSN: 2581-4664

was analyzed by stepwise multiple regression analysis. The stepwise regression analysis regarding the entrepreneurship orientation scale is presented in Table 14.

Table 14. The result of stepwise regression analysis regarding prediction of entrepreneurship orientation

\begin{tabular}{|llllllllll|}
\hline Model & $\mathrm{B}$ & Std. Dev. & $\beta$ & $\mathrm{t}$ & $\mathrm{p}$ & $\mathrm{R}$ & $\mathrm{R} 2$ & $\mathrm{~F}$ & $\mathrm{p}$ \\
\hline 1 (coefficient) & 55.42 & 3.33 & & 16.66 & .000 & & & & \\
Self Directedness & -.35 & .11 & -.20 & -3.09 & .002 & .20 & .04 & 9.51 & .002 \\
\hline
\end{tabular}

The ANOVA table regarding the stepwise regression analysis has revealed that the described regression model is statistically significant. As seen in Table 3, the stepwise regression analysis did not include the novelty seeking variable since it could not predict the entrepreneurial orientation scale at a significant level; the self-directedness variable was processed in the stepwise regression analysis process. The self-directedness scale explains $4 \%$ of the total variance of the entrepreneurship orientation $\left[\mathrm{F}_{(1,222)}=9.51 ; \mathrm{p}<0.01\right]$. According to Cohen $(1988$; as cited in Özsoy \& Özsoy, 2013, p. 339), the effect size results are explained as $\left(\mathrm{R}^{2}\right)$ : .0196 small; .1300 medium; .2600 big effect values. Therefore, it can be said that the $\mathrm{R}^{2}$ value $\left(\mathrm{R}^{2}=.04\right)$ obtained from this analysis has a small effect size.

\section{RESULTS AND DISCUSSION}

In this research, in line with the opinions of business people operating in Yozgat province in 2019, the effect of temperament and character of business people on entrepreneurship orientations and economic development level of the province was studied. Research findings revealed that in Yozgat business people's novelty seeking, self-directedness and cooperativeness levels, which are sub-scales of temperament and character inventory, are above the mean. Entrepreneurs should have the following characteristics; being innovative, which is one of the basic features expected to be found in entrepreneurial individuals, in the context of being open to new ideas and evaluating new business opportunities (Bozkurt 2007; Yalçıntaş 2010), self-directedness in the context of proper self guidance and sustaining the business (Esen \& Conkar 1999; Üzülmez 2008) and cooperativeness in order to achieve the desired success in the business and cooperate with other individuals when necessary (Üzülmez 2008). Therefore, the fact that these traits of the business people participating in the research are above the mean seems to be important in terms of supporting that they demonstrate entrepreneurial personality traits.

In the research, entrepreneurship orientation of business people was found at high level. Finding their entrepreneurship orientation levels at high level is considered as an expected situation because the people participated in the research are business people. Since the temperament and character of individuals have a great importance on their behaviors, it is inevitable that entrepreneurship orientations are also affected from them. Therefore, it is considered that entrepreneurial personality traits of business people are effective in attaining such a finding as a result of the research. Orhan (2017) stated that, the personality traits of the individual affect the individual's entrepreneurial competence, and at the same time, contextual traits caused from the individual (family history, entrepreneurial past, age, gender) and environment (university environment, tolerance to uncertainty) play a major role in transforming the entrepreneurial potential into entrepreneurial actions. Similarly, 


\section{International Journal of Business Management and Economic Review}

Vol. 4, No. 03; 2021

ISSN: 2581-4664

Uçkun, Korkmaz and Yener (2019) reported that social environment variables are effective on individual behaviors. Considering these ideas, whether the entrepreneurship orientation of the business people and their temperament and character traits differentiate significantly with some demographic variables were studied. As a result of the analysis, it was found that the mean scores of business people's entrepreneurship orientation, novelty seeking, self-directedness and cooperativeness scales did not differentiate significantly according to the gender of the participants, their duties, the operation period of the institution they work for, the sectors they work in and the number of employees in their institutions. However, the mean scores of the participants' entrepreneurship orientation and novelty seeking scales showed a significant difference terms of age variable; on the other hand, self-directedness and cooperativeness scales did not significantly differentiate in terms of age variable. For the entrepreneurship orientation scale, it was revealed that this difference was generally in favor of participants aged 40 and under, between participants aged 40 and under and participants aged 50 and over. This finding is very important in terms of revealing that the entrepreneurship orientation of individuals decreases after a certain age compared to the individuals at an earlier age. On the other hand, for the novelty seeking scale, this difference was found to be in favor of participants aged 30 and younger, between participants aged 30 and younger, participants aged 31-40 and participants aged 50 and above. This finding is also noteworthy in terms of revealing that young business people's novelty seeking is higher than older people. Sönmez \& Toksoy (2014) found in their research that the highest number of entrepreneurs is among the 30-44 age group.

It was found out that the means rank of the scores of the entrepreneurship orientation and cooperativeness scales of the participants show a significant difference according to the export variable of the institution business people work for; the means rank of the novelty seeking and selfdirectedness scales did not differentiate significantly according to export variable. It was indicated that this difference was in favor of non-exporters for the entrepreneurship orientation scale, and in favor of the exporters for the scale of cooperativeness. In other words, entrepreneurship orientation of business people in Yozgat province who do not export is higher than those who export. Furthermore, the findings demonstrated that business people in Yozgat province who export are more likely for cooperativeness than those who do not export. When "entrepreneurship" is mentioned, the first thing that comes to mind is that an entrepreneurial individual establishes a new business in new markets (Aldemir 2011). These findings are considered to be related to the entrepreneur types of business people in Yozgat province. The entrepreneurs in Yozgat province exhibit the tradesman type entrepreneurs (Smith 1967), and thus, exporting is not generally expected from such entrepreneurs. However, exporting is undoubtedly an activity that requires mutual cooperation both at home and abroad at a certain level; thus, it is meaningful that the means rank scores of the cooperativeness scale with this idea are higher in favor of the exporters. Sonmez and Toksoy (2014) reported that the culture of partnership in business is not developed in Turkey and businesses is generally tend to belong to a single person. Therefore, while cooperativeness is significantly high in exporters, its remaining same in non-exporters is considered as a result of such a situation.

Smith (1967), who has made one of the best-known classifications related to entrepreneur typologies, examined entrepreneurs in two categories as "tradesman type entrepreneur" and "opportunistic entrepreneur". In short, tradesman type entrepreneur is a type of entrepreneur who has low education level, comes from the experience of workmanship, whose financial resources are limited with their personal savings and the money he receive from the people around, and most importantly, he does 


\section{International Journal of Business Management and Economic Review}

Vol. 4, No. 03; 2021

ISSN: 2581-4664

not have management skills. Opportunist entrepreneur is a type of entrepreneur who has a middle class background, has a broader education, can see new opportunities, is very innovative and can develop various strategies, uses a wide variety of financial resources and has management experience (Rauch and Frese 2000; as cited in Özkul \& Dulupçu 2007). Based on this information, it is considered that the business people in Yozgat province generally are tradesman entrepreneur types since there is a negative correlation between the entrepreneurship orientation of the participants and the variables of self-directedness and novelty seeking. Entrepreneur types may vary by province, for example, in a study examining entrepreneurship behaviors of different provinces, Özkul and Dulupçu (2007) found that entrepreneurs in Antalya exhibit more opportunistic type entrepreneurship, while entrepreneurs in Isparta exhibit more tradesman type entrepreneurship.

The findings demonstrated that the temperament and character traits of the participants related to entrepreneurship had a positive effect on the economic development level of the city. It is accepted by all the countries of the world that entrepreneurship has started to take place as a fundamental element in the development strategies of countries such as economic growth, employment and social progress (Balaban \& Özdemir 2008) and is an important dynamic to economic development (Palaz \& Turgut 2009). Entrepreneurship has contributed to positive developments in individual and integrative welfare, especially with its contributions on unemployment (Orhan 2017). On the other hand, entrepreneurship is also important for developing countries, which strive to reach the level of competitiveness in international markets (UNCTAD 2004; as cited in Boz 2008). Similarly, the entrepreneurs of the province play an important role in developing countries in the rapid development of the provinces, of which economic growth rates are below the national average. The focus of production on certain regions of the country during the growth process of developing countries causes domestic migration and slows down growth after a certain period of time. Development and advancement of a country depend on its ability to raise entrepreneurs who have the ability to adapt to rapidly changing conditions throughout the country and that can contribute to economic growth. Economic growth of a country depends on growth and contribution of all provinces rather than only "high income" provinces. In Turkey, middle-income and low-income provinces do not differ, significantly. High income provinces are the locomotives for economic development. Hence, focus of this study is understanding the behavior of entrepreneurships operating in low income provinces.

In conclusion; (i) the level of novelty seeking and entrepreneurship orientation of business people in Yozgat are at high level; (ii) the level of self-directedness and cooperativeness of business people are at moderate level; (iii) there is a low level relationship between business people's self-directedness and novelty seeking levels and entrepreneurship orientations; (iv) only self-directedness has a significant effect on entrepreneurship orientations of business people. Obtained results are informative to find out the key factors for prompting eager and ability to make significant contributions to overall GDP of entrepreneurships operating in low income provinces. Following suggestions were made in line with the findings obtained from the research; (i) this research was carried out using the quantitative research method, a similar research can be carried out using the qualitative research method to obtain more in-depth information about the research questions; (ii) by conducting a similar research covering other provinces, a more general conclusion can be reached on a regional scale; (iii) other variables considered to be influential in the economic development of their provinces and entrepreneurship orientations of business people may be examined.

\section{REFERENCES}

Aldemir, B. 2011. Küçük ve orta boy inşaat firmalarının girişimcilik yönelimi. Unpublished Master 


\section{International Journal of Business Management and Economic Review}

Vol. 4, No. 03; 2021

ISSN: 2581-4664

Thesis, İstanbul Technical University, İstanbul, Turkey.

Arkar, H., Sorias O., Tunca Z., Şafak C., Alkın T., Akdede B. B. \& Cimilli C. 2005. Mizaç ve Karakter Envanteri’nin Türkçe formunun faktör yapısı, geçerlik ve güvenilirliği. Türk Psikiyatri Dergisi 16(3): 190-204

Balaban, Ö. \& Özdemir Y. 2008. Girişimcilik eğitiminin girişimcilik üzerine etkisi: Sakarya Üniversitesi İİBF örneği. Girişimcilik ve Kalkınma Dergisi 3(2):133- 14.

Boz, M. 2008. Başarılı girişimcilikte yenilik ortaya koymanın önemi: Kırgızistan örneği. KırgızistanTürkiye Manas Üniversitesi Yayınları:112 Kongreler Dizisi:16.

Bozkurt, Ö. 2007. Girişimcilik eğiliminde kişilik özelliklerinin önemi. Girişsimcilik ve Kalkınma Dergisi 1(2):93-111

Büyüköztürk, Ș. 2011. Sosyal Bilimler için Veri Analizi El Kitabı (17. bs.). Ankara: Pegem Akademi. Cuervo, Á., Ribeiro, D. \& Roig, S. 2007. Entrepreneurship: Concepts, theory and perspective. Introduction. In Entrepreneurship. Berlin, Heidelberg: Springer.

Çiçeklioğlu, H. \& Afşar A. 2017. Girişimcilik eğitimi kurslarına katılan bireylerin kişilik özelliklerinin girişimcilik eğilimlerine olan etkilerinin incelenmesi. International Journal of Disciplines Economics and Administrative Sciences Studies 3(1): 1-16

Durukan, T. 2007. Dünden bugüne girişimcilik ve 21.yüzyılda girişimciliğin önemi. Girişimimcilik ve Kalkinma Dergisi (Journal of Entrepreneurship and Development) 1(2): 25-38

Eroğlu, Ş. G., Vural, M. \& Eroğlu, F. 2019. Mizah tarzları ile girişimcilik eğilimi arasındaki iliş̧i üzerine bir araştırma. International Conference On Eurasian Economies.

Esen, A. \& Conkar, K. 1999. Orta Anadolu (Konya, Kayseri, Sivas ve Tokat) Girişimcilerinin SosyoEkonomik Özellikleri, İsletmecilik Anlayış̧ları ve Beklentileri Araştırması. Konya Ticaret Odası Kültür ve Eğitim Yayınları No.18.

Gartner, W. B. 1985. A conceptual framework for de scribing the phenomenon of new venture creation. Academy of Management Review 10: 696-706

George D. \& Mallery, M. 2003. Using SPSS for Windows Step by Sstep: A Simple Guide and Reference. Boston, MA: Allyn \& Bacon.

İnce, A.R. \& Topcu M.K. 2017. Girişimcilik yöneliminin işe bağlanma üzerindeki etkisinde algılanan örgütsel desteğin rolü. Kara Harp Okulu Bilim Dergisi 27(2): 1-27

Kao, J. 1993. The worldwide web of Chinese business. Harvard Business Review March-April: 2436

Karasar, N. 2012. Bilimsel Araş̧ırma Yöntemi.(24. Basım). Ankara: Nobel Yayın Dağıtım.

Keskin, S. 2017. Kadın ve erkek girişimciler arasındaki farklılıklar. Mersin Üniversitesi Sosyal Bilimler Enstitüsü Dergisi 1(1): 64-76

Kose, S., Sayar K., Kalelioglu U., Aydin N., Ak I., Kirpinar I., Reeves R.A., Przybeck T.R., Cloninger C.R. 2004. Turkish version of the TCI: Reliability, validity, and factorial structure. Bull. Clin. Psychopharmacol. 14: 107-131

Köklü N., Büyüköztürk Ş. \& Çokluk Bökeoğlu Ö. 2006. Statistics for Social Sciences. Ankara: Pegem-A Publication.

Memiş, H., Paksoy H.M. \& Paksoy S. 2007. Bölgesel kalkınmada kadın girişimciliğinin önemi: GAP bölgesinde bir araştırma. Çanakkale Onsekiz Mart Üniversitesi I.I.I.B.F. Girişimcilik ve Kalkınma Dergisi 2:137-153

Miller, D. 1983. The correlates of entrepreneurship in three types of firms. Management Science 29: $770-791$ 


\section{International Journal of Business Management and Economic Review}

Vol. 4, No. 03; 2021

ISSN: 2581-4664

Orhan, K. 2017. Girişimcilik Potansiyeli Belirleme Envanteri'nin (Entrepreneurial Potential Assessment Inventory-EPAI) Türkçe'ye uyarlanması ve psikometrik özellikleri. ODÜ Sosyal Bilimler Araştırmaları Dergisi (ODÜSOBİAD) 7(3): 609-625

Özgün, M.S. 2007. Okul psikolojik danışmanlarının kişilik özellikleri ile mesleki yetkinlik beklentileri arasındaki ilişkinin incelenmesi. Unpublished Master Thesis, Çukurova University, Adana, Turkey.

Özkul, G. \& Dulupçu M. A. 2007. Kişisel gelişimin girişimci tipleri üzerine etkisi: Antalya-Isparta illerinde bir inceleme. Girişimcilik ve Kalkınma Dergisi 2(2): 89-92Özsoy, S. \& Özsoy G. 2013. Effect size reporting in educational research. İlkögretim Online 12(2): 334-346

Palaz, S., \& Turgut B. 2009. Kadın girişimcilerin kişisel ve iş yaşamına ilişkin özellikleri, motivasyonları ve beklentileri üzerine bir araştırma: Bandırma örneği Girişimcilik ve Kalkınma Dergisi 4(1): 99-115

Reynolds, P.D. 2005. Understanding business creation: Serendipity and scope in two decades of business creation studies. Small Business Economics, 24: 359-364

Sarıstaş, A. \& Duran G. 2017. Üniversite öğrencilerinin girişimcilik eğilimlerinin tespitine ilişkin bir araştırma. Anemon Muş Alparslan Üniversitesi Sosyal Bilimler Dergisi 5(1): 147-165

Śledzik, K. 2013. Schumpeter's view on innovation and entrepreneurship. In Management Trends in Theory and Practice edited by S. Hittmar. University of Zilina \& Institute of Management by University of Zilina. Faculty of Management Science and Informatics,

Smith, N.R. 1967. The Entrepreneur and His Firm: The Relationship Between Type of Man and Type of Company. Occasional Papers, Bureau of Business and Economic Research, Michigan State University, 109.

Smith, K., Gannon M., Grimm C. \& Mitchell T. 1988. Decision making behaviour in smaller entrepreneurial and larger professionally managed firms. Journal of Business Venturing 3: 223-232

Sönmez, A. \& Toksoy A. 2014. Türkiye'de girişimcilik ve Türk girişimci profili üzerine bir analiz. Yönetim ve Ekonomi 21(2): 41-58

Taşlıyan, M., Çiçeklioğlu, H. \& Yılmaz, Ö. İ. 2017. Üniversite öğrencilerinin kişilik özelliklerinin girişimcilik eğilimleri üzerine olan etkileri: Bir alan çalışması. 4. Uluslararası Çin'den Adriyatik'e Sosyal Bilimler Kongresi, 03-04 Aralık, Gaziantep, Türkiye.

Totan, T., Aysan F. \& Bektaş M. 2010. Prospective teachers' temperament, character, and personality traits. Inonu University Journal of the Faculty of Education (INUJFE) 11(2): 19-43

TUIK (Türkiye İstatistik Kurumu) 2020. İstatistik göstergeler-il göstergeleri.https://biruni.tuik.gov.tr/ilgosterge/?locale=tr (accessed 14 January 2020).

Uçkun, C. G., Korkmaz F. \& Yener S. 2019. Öz-yönelimin yaşam tatmini üzerindeki etkisinde girişimcilik algısının aracı rolü. Uluslararası Sosyal ve Eğitim Bilimleri Dergisi 6(12): 148-166 Üzülmez, H. 2008. Girişimcilik ve Konya'da girişimciliğin geleceği. Girişimcilik ve Kalkınma Dergisi 3(2): 21-31

World Bank. 1978. World development indicators; World development report. Washington, D.C. : World Bank Group. http://documents.worldbank.org/curated/en/297241468339565863/Worlddevelopment-report-1978 (accessed 14 January 2020).

Yalçıntaş, M. 2010. Çağımızda girişimcilik. Girişimcilik ve Kalkınma Dergisi 5(1): 95-99

Yener, S. 2018. Girişimcilik ve benlik. In 21. yy. Becerileri edited by A.D. Öğretir Özçelik \& M.Nur. Ankara: Pegem Yayınevi.

Yılmaz, E.D., Gençer A.G., Ünal Ö. \& Aydemir Ö. 2014. Enneagram'dan dokuz tip mizaç modeli'ne: 


\section{International Journal of Business Management and Economic Review}

Vol. 4, No. 03; 2021

ISSN: 2581-4664

Bir öneri. Eğitim ve Bilim 39(173): 396-417

Yılmaz, H., Karahan A. \& Arslan E. 2019. Girişimcilik yönelimi ve örgütsel vatandaşılık davranışı arasındaki ilişkilerin belirlenmesi: Tarımsal mekanizasyon imalatçısı işletmeler bağlamında bir araştırma. Selçuk Üniversitesi Sosyal ve Teknik Araştırmalar Dergisi 17: 1-23 